\title{
Coronary endarterectomy in left anterior descending artery combined with coronary artery bypass grafting - midterm mortality and morbidity
}

\author{
Wojciech Domaradzki ${ }^{1}$, Krzysztof Sanetra ${ }^{1}$, Jolanta Krauze ${ }^{1}$, Leszek Kinasz ${ }^{2}$, Justyna Jankowska-Sanetra², \\ Małgorzata Świątkiewicz ${ }^{1}$, Krzysztof Paradowski ${ }^{3}$, Marek Cisowski ${ }^{1}$
}

${ }^{1}$ American Heart of Poland, First Department of Cardiac Surgery, Bielsko-Biała, Poland

${ }^{2}$ American Heart of Poland, Second Department of Cardiology, Bielsko-Biała, Poland

${ }^{3}$ American Heart of Poland, Department of Anaesthesiology and Intensive Care, Bielsko-Biała, Poland

Kardiochirurgia i Torakochirurgia Polska 2015; 12 (4): 304-308

\begin{abstract}
Introduction: Completeness of myocardial revascularization is essential in surgical treatment of coronary artery disease. The aim of this study is to determine the effectiveness of coronary endarterectomy as an adjunct to coronary artery bypass grafting (CABG) in the most difficult cases.

Material and methods: Among 1559 patients who had CABG in our department, the cases of 17 who underwent an adjunct left anterior descending endarterectomy were analyzed. All procedures were performed with median sternotomy, extracorporeal circulation and in mild hypothermia $\left(34^{\circ} \mathrm{C}\right)$, by the same surgeon. No coronary artery endarterectomy was planned before surgery.

Results: There was no infarction or cardiac arrest during hospitalization. Only one patient required mechanical circulatory support (intra-aortic balloon counterpulsation). Each patient was contacted and investigation for major adverse cardiac and cerebrovascular events (MACCE) was performed. Eleven patients (65\%) already underwent midterm clinical evaluation. There was no death, myocardial infarction or cerebrovascular incident during the entire period (mean follow-up at 15.3 months). One patient required urgent coronarography due to chest pain. No other patient had chest pain or significant deterioration of ventricular function in echocardiography.

Conclusions: Outcomes and potential indications for performing left anterior descending coronary endarterectomy as an adjunct to $C A B G$ are discussed.
\end{abstract}

Key words: $C A B G$, endarterectomy, $C E$, coronary artery disease.

\section{Streszczenie}

Wstęp: Kompletność rewaskularyzacji mięśnia sercowego jest niezbędna w leczeniu chirurgicznym choroby wieńcowej. Celem badania była ocena skuteczności endarterektomii przeprowadzanej jako zabieg dodatkowy przy standardowej procedurze pomostowania aortalno-wieńcowego $\mathrm{w}$ najtrudniejszych przypadkach klinicznych.

Materiał i metody: Spośród 1559 pacjentów, którzy przeszli pomostowanie aortalno-wieńcowe na naszym oddziale, wybrano i przeanalizowano przypadki 17 pacjentów, których poddano również wspomagającej endarterektomii w zakresie tętnicy lewej przedniej zstępującej. Wszystkie zabiegi były wykonane przez tego samego chirurga, z zastosowaniem sternotomii pośrodkowej i krążenia pozaustrojowego, w warunkach łagodnej hipotermii $\left(34^{\circ} \mathrm{C}\right)$. Żadna z endarterektomii tętnic wieńcowych nie była planowana przedoperacyjnie.

Wyniki: W czasie hospitalizacji nie doszło do zawału ani zatrzymania krążenia. Tylko jeden z pacjentów wymagał mechanicznego wspomagania krążenia (kontrapulsacji wewnątrzaortalnej). Nawiązano kontakt ze wszystkimi pacjentami i przeprowadzono badania w kierunku poważnych niepożądanych zdarzeń sercowych i mózgowo-naczyniowych (major adverse cardiac and cerebrovascular events - MACCE). Jedenastu pacjentów (65\%) zostato już poddanych średnioterminowej ocenie klinicznej. W całym okresie obserwacji (średnio: 15,3 miesiąca) nie doszło do zgonu, zawału mięśnia sercowego czy epizodu naczyniowo-mózgowego. Jeden z pacjentów wymagał pilnej koronarografii ze względu na ból w klatce piersiowej. U żadnego z pozostałych pacjentów nie występował ból w klatce piersiowej; nie zaobserwowano też pogorszenia funkcji skurczowej serca w badaniu echokardiograficznym.

Wnioski: Artykuł omawia wyniki zabiegów oraz potencjalne wskazania do endarterektomii wieńcowej tętnicy lewej przedniej zstępującej jako leczenia wspomagającego pomostowanie aortalno-wieńcowe.

Słowa kluczowe: $C A B G$, endarterektomia, $C E$, choroba niedokrwienna serca.

Address for correspondence: Krzysztof Sanetra MD, American Heart of Poland, First Department of Cardiac Surgery, 101 Armii Krajowej St., 43-316 Bielsko-Biała, Poland, phone: +48 692030 003, e-mail: krzyssan@poczta.onet.pl 


\section{Introduction}

Scientific research proves that completeness of myocardial revascularization is essential in surgical treatment of coronary artery disease (CAD) [1-3]. The patient profile is greatly different than it used to be. Many of them are qualified for surgery when vessel lesions are very advanced and diffused, which makes proper grafting hardly possible. The problem is even more serious when it occurs within arteries that are crucial to achieve optimal clinical effect. Failure in obtaining optimal blood flow in the left anterior descending (LAD) artery may have a catastrophic clinical outcome.

In those cases it is justified to use additional forms of therapy. Coronary endarterectomy (CE) was introduced as a surgical technique of CAD treatment before coronary artery bypass grafting (CABG) [4]. The first CE procedures were performed in the 1950s without extracorporeal circulation. They were quickly replaced with a more efficient method though. There are some observations that prove combined CABG and CE to be helpful in achieving complete myocardial revascularization in the most difficult cases. The aim of this study was to determine the effectiveness of coronary endarterectomy as an adjunct to coronary artery bypass grafting in those patients.

\section{Material and methods \\ Patients}

One thousand five hundred fifty-nine patients had CABG surgery in our department in 2012-2014. Cases of 17 patients ( $1 \%-12$ male and 5 female) aged $47-75$ (62.3 \pm 8.8 ) who underwent combined CABG + LAD endarterectomy were analyzed. The profile was quite varied as it includes coronary artery disease and comorbidities (Table I). On admission to hospital, 2 patients were classified as CCS (Canadian Cardiovascular Society Angina Grading Scale) I, 2 as CCS II, 11 as CCS III, and 2 as CCS IV. Ten (59\%) never had a myocardial infarction (MI), 5 (29\%) were hospitalized due to MI once, and 2 (12\%) had MI twice. In 5 cases (29\%) percutaneous myocardial revascularization $(\mathrm{PCl})$ was performed more than one month before surgery. Among them, 3 patients had direct LAD percutaneous treatment. All LAD $\mathrm{PCl}$ interventions were successful and were related to the medial segment of the artery. The other 2 patients with $\mathrm{PCI}$ underwent direct RCA stenting.

\section{Procedure}

All analyzed procedures were performed with median sternotomy, extracorporeal circulation (ECC) and in mild hypothermia $\left(34^{\circ} \mathrm{C}\right)$, by the same surgeon. Not a single CE was planned before surgery - decisions were made intraoperatively and based on the possibility of achieving proper $L A D$ revascularization. Every patient underwent LAD endarterectomy and acquired a left internal mammary artery to LAD graft (LIMA-LAD). Coronary endarterectomy was performed with both the closed (small arteriotomy with gentle traction to remove most of the intracoronary material - most cases) and the open method (arteriotomy that allows the full-length lesion to be visualized) - the choice depended on the opportunity to achieve a proper effect with the minimal possible endothelial trauma. At first the vessel was opened with only a small incision, standard for normal coronary artery bypass grafting. After evaluating the anatomy of a particular artery, the incision was extended slightly. Further extension of the incision was made when pulling the plaque with gentle traction was unsuccessful. A surgical probe of small diameter was used with caution to help to separate the plaque from the vessel wall (Fig. 1-4). Completeness of each endarterectomy was evaluated using a surgical probe of diameter adjusted to the current vessel. If possible, intracoronary material was removed with gentle traction from side branches of the LAD. Failure to retrieve the plaque from the side branch did not result in further expansion of the procedure. Regardless of incision length, LAD arteriotomy was directly covered with the LIMA-LAD anastomosis (Fig. 5).

\section{Hospitalization}

On the first day after the procedure each patient received dual antiplatelet therapy (ASA in a dose of $150 \mathrm{mg} / \mathrm{d}$ and clopidogrel in a dose of $75 \mathrm{mg} / \mathrm{d}$ ) with the intention of continuation for at least three months. Low-molecularweight heparin $(\mathrm{LMWH})$ was continued until the patient was fully mobilized (according to guidelines there was no indication for long-term anticoagulation in any case).

\section{Clinical evaluation}

Each patient had a clinical evaluation at least six months after surgery. Overall clinical outcome was analyzed. Investigation for MACCE (defined as death, myocardial infarction, repeat $\mathrm{PCl}$ or cardiac surgery and cerebrovascular episodes) and echocardiographic as well as electrocardiographic assessment was performed. Myocardial infarction was defined arbitrarily by elevation of cardiac biomarker values > 10 in patients with normal baseline cTn values; either new pathological Q waves or new LBBB; angiographic documented new graft or new native coronary artery occlusion; imaging evidence of new loss of viable myocardium or new regional wall motion abnormality.

Tab. I. Patient profile

\begin{tabular}{lll}
\hline Diabetes & 7 & $41 \%$ \\
\hline Insulin treatment & 2 & $12 \%$ \\
\hline Arterial hypertension & 15 & $88 \%$ \\
\hline Hypercholesterolemia & 14 & $82 \%$ \\
\hline Obesity & 10 & $59 \%$ \\
\hline Carotid stenosis & 2 & $12 \%$ \\
\hline Limb ischemia & 1 & $6 \%$ \\
\hline $\begin{array}{l}\text { Chronic obstructive pulmo- } \\
\text { nary disease }\end{array}$ & 1 & $6 \%$ \\
\hline Gastrointestinal ulceration & 1 & $6 \%$ \\
\hline Smoking & 7 & $41 \%$ \\
\hline
\end{tabular}



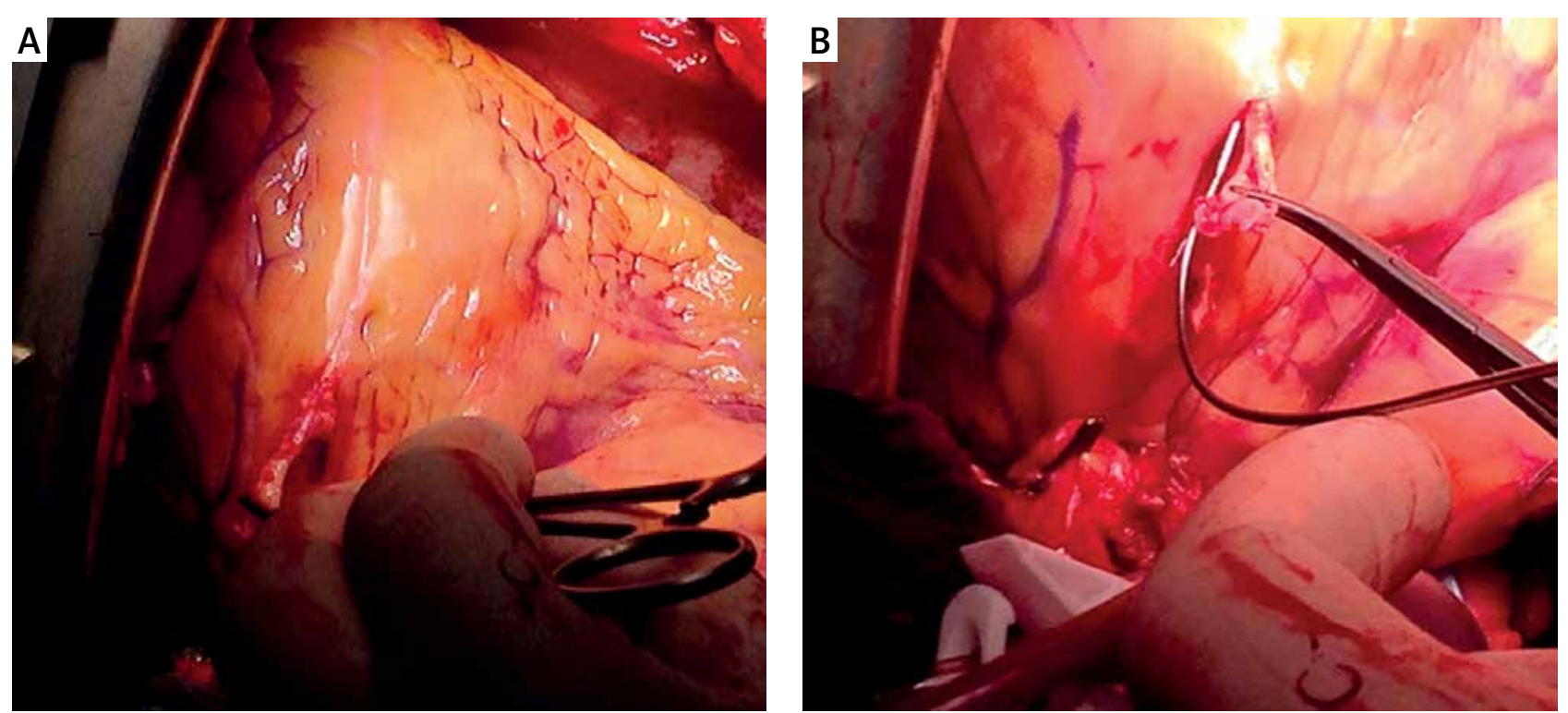

Fig. 1. Performing coronary endarterectomy

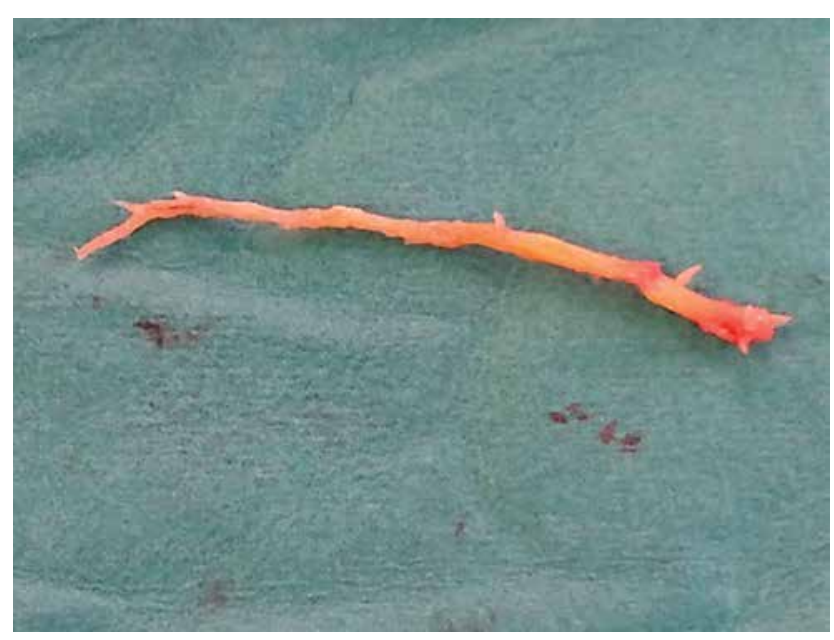

Fig. 2. Removed plaque
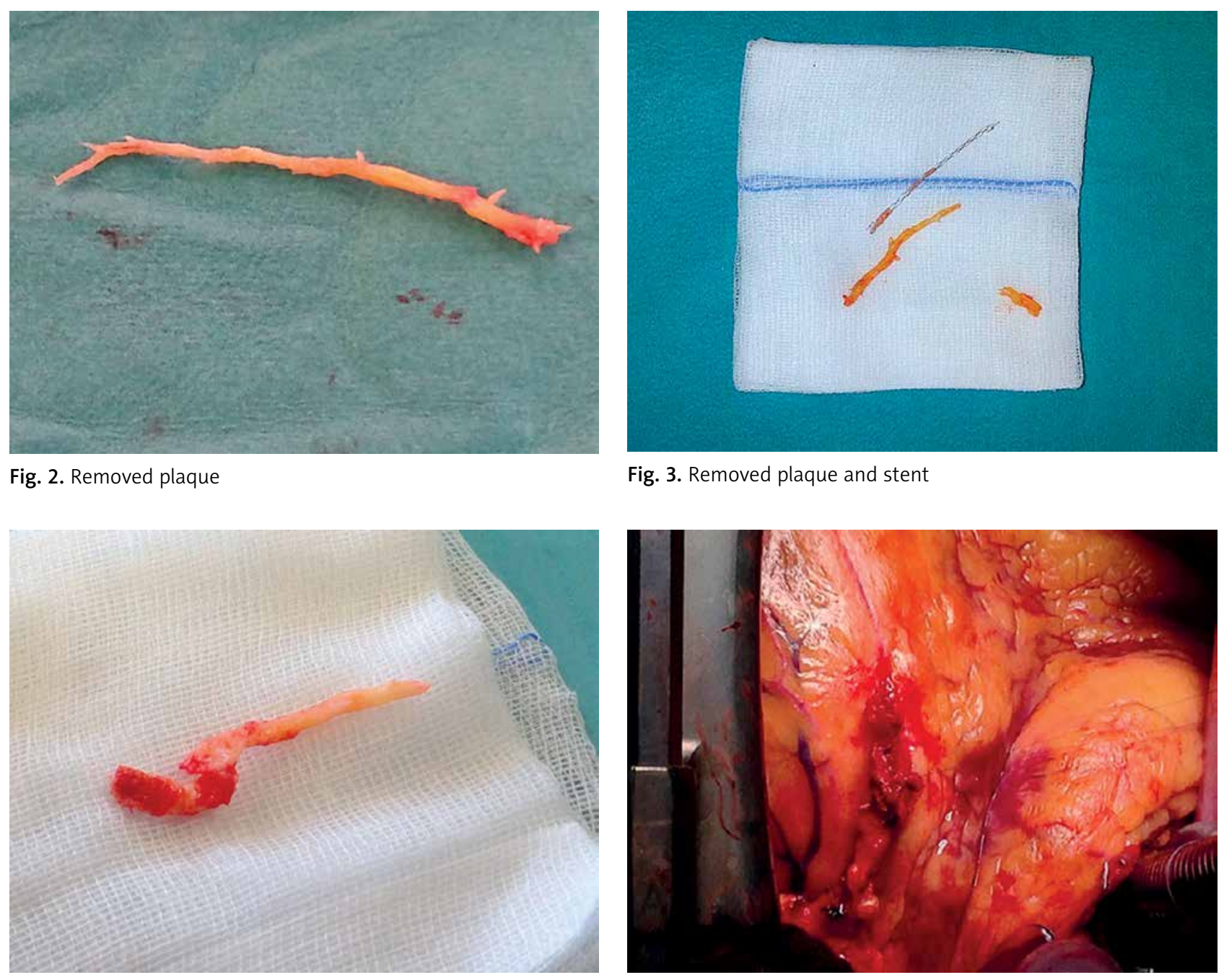

Fig. 4. Removed plaque

Fig. 3. Removed plaque and stent

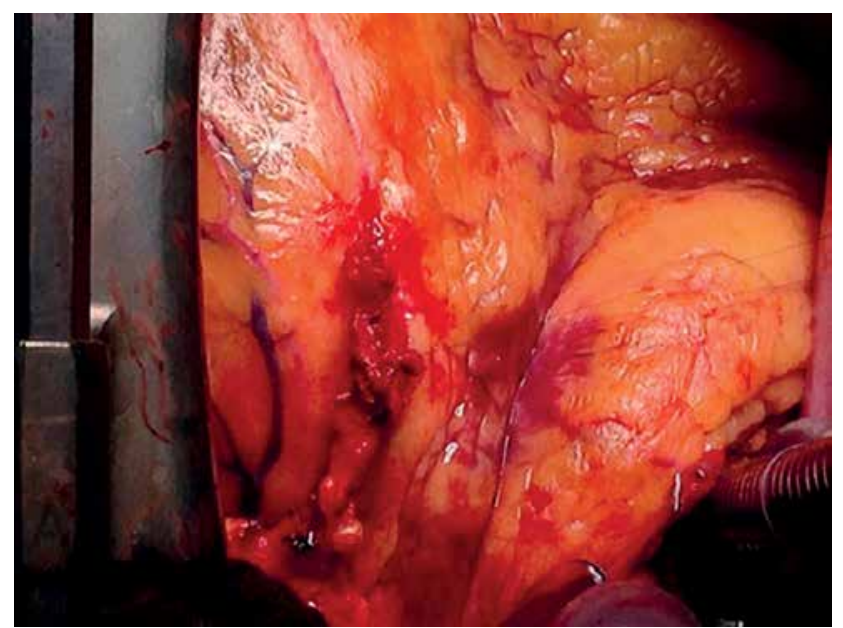

Fig. 5. Completed left internal mammary artery to left anterior descending (LIMA-LAD) anastomosis 


\section{Results}

\section{Hospitalization}

Patients had respectively two (8-47\%), three (8-47\%) and four (1-5.8\%) bypass grafts done. Mean extracorporeal circulation time was $62 \mathrm{~min}$ (33-92 $\mathrm{min}$ ) and mean time of aortic cross-clamp was $42 \mathrm{~min}$ (23-62 min).

Ten (59\%) and six (35\%) patients had an LAD incision length of around $1.5-2 \mathrm{~cm}$ and $2-3 \mathrm{~cm}$, respectively. One patient (5.8\%) required an incision length of around $4 \mathrm{~cm}$. One patient had his stent removed along with the plaque (Fig. 3).

Seven patients (41\%) required catecholamine infusion intraoperatively. One patient (5.8\%) required repeat ECC. $\mathrm{He}$ had an LAD incision length of around $2.5 \mathrm{~cm}$. Completeness of CE was evaluated using a surgical probe of diameter $1 \mathrm{~mm}$, and an occlusion in the distal part of the LAD was revealed. Therefore, after failure of withdrawal from extracorporeal circulation, an Ao-SV-LAD anastomosis was done distally to the LIMA-LAD anastomosis and the occlusion. The same patient required mechanical circulatory support - an intraaortic balloon pump (IABP) was placed during surgery and was removed after 24 hours. He did not meet the criteria of myocardial infarction. His further hospitalization was uneventful and he was discharged to the rehabilitation department.

There was one (5.8\%) mediastinal re-exploration due to a high volume of drainage $(1300 \mathrm{ml})$.

Five patients (29\%) needed inotropic support for the first few hours after the surgery. Four of them required only a small dose of dopamine (up to $3 \mu \mathrm{g} / \mathrm{kg} / \mathrm{min}$ ), and one received high doses of dopamine and continuous levonor infusion. No death or perioperative $\mathrm{MI}$ was reported. Mean mechanical ventilation time was $8 \mathrm{~h}$ (2.6-36 h). Mean total drainage volume was $800 \mathrm{ml}(450-1660 \mathrm{ml})$. Three patients (18\%) required a packed red blood cell transfusion postoperatively. Atrial fibrillation was noted in 3 patients (18\%). It was successfully treated with amiodarone and each patient regained sinus rhythm before discharge from the department. Time of in-hospital stay was 6-11 days (mean 7.6 days).

\section{Follow-up}

Ten patients (59\%) have already been examined for midterm follow-up in our hospital unit (examination for patients operated on more than six months previously). One (6\%) answered the midterm follow-up call survey questions. Mean follow-up was at 15.3 months.

The remaining 6 patients ( $35 \%$ of our CE + CABG group) visited our hospital unit for short-term clinical assessment. They presented with no chest pain (CCS I) and echocardiography did not reveal any new contraction disorders. None of them required any cardiovascular intervention or admission to hospital. All are under the regional cardiologist's control. They are regularly contacted and have their clinical evaluation visits scheduled with the intention to preserve the midterm-follow up in the entire group.
In the whole group of $C A B G+C E$ patients there was no death in the entire period. None of the patients had a myocardial infarction or cerebrovascular incident.

In one case (9\%) there was a necessity for urgent coronarography due to chest pain. It was performed 8 months after an uncomplicated CABG + CE procedure and uneventful hospitalization. The CE procedure in this patient was performed with an incision around $2 \mathrm{~cm}$ long and completeness of endarterectomy was evaluated by a $1 \mathrm{~mm}$ surgical probe.

The coronary angiography revealed that all grafts (venous as well as arterial) were patent. It visualized the LAD occlusion distally from the LIMA graft suturing site though. The diameter of the LAD in this patient was $2 \mathrm{~mm}$. The attempt to restore LAD patency below the LIMA-LAD anastomosis failed, and the patient was treated pharmacologically. At the time of follow-up examination (13 months after CABG $+\mathrm{CE}$ and 5 months after the previously mentioned coronarography) he showed no chest pain (classified as CCS I). The patient's echocardiography showed a fall of ejection fraction (40\% versus $50 \%$ in postoperative examination). He also had a noticeable contraction disorder (hypokinesis of anterior and inferior wall as well as intraventricular septum versus hypokinesis of inferior wall and intraventricular septum in post-surgery examination). The patient is currently being followed up regularly and presents CCS I/CCS II.

As mentioned before, 10 patients (59\%) have already undergone midterm echocardiographic assessment. It allowed us to evaluate myocardial function precisely, especially within the anterior wall. Six patients (54\%) had a noticeable rise in ejection fraction (EF) compared to their preoperative examination. Three (27\%) had no remarkable improvement or deterioration. Only one patient (the one described previously - 9\%) had a significant fall of EF with worsening of anterior wall motion. Improvement or no significant change in anterior wall motion was observed in the other patients.

\section{Discussion}

It appears that LAD endarterectomy combined with LIMA grafting is the only possibility to achieve completeness of revascularization in some cases. Published analyses with larger numbers of patients confirm our observation and indicate good efficiency of this method in this group.

Data referring to perioperative mortality among patients who underwent a combined CABG + CE procedure are quite different among hospital units. Most results are estimated between 2 and 8\% [5-10]. It is probably due to the heterogeneity of patient groups and research methodology. Byrne and co-authors analyzed 196 patients who underwent selective LAD CE + CABG. Mortality was 3\%. Three percent of patients suffered from myocardial infarction within the LAD-dependent myocardial area. At oneyear follow-up $90 \%$ of patients were angina-free [11].

Myocardial infarction (MI) remains the complication that occurs most often after the CE + CABG procedure. The first hours after surgery are crucial $-M I$ is usually re- 
lated to acute thrombosis within the vessel due to intraoperative endothelial damage. However, there is huge divergence in statistical data - authors estimate the frequency of early perioperative $\mathrm{MI}$ to be between 1 and $19 \%$, depending on the cardiac surgery unit $[5,12]$. The number of $\mathrm{MI}$ in mid- and long-term follow-up is much lower - some reports show that the incidence of $\mathrm{MI}$ in patients after $\mathrm{CABG}+\mathrm{CE}$ is equal to that in patients who underwent CABG solely [10].

All studies show unequivocally that $\mathrm{MI}$ is more frequent in patients after CABG + CE than in patients after sole CABG. Despite this fact, Damien et al. reported that in only $27.8 \%$ of patients did it relate to area depending on the vessel that underwent $C E$ [10]. It is suggested that higher frequency of $\mathrm{MI}$ in patients after CABG + CE is not only an effect of the endarterectomy procedure but it mainly due to the advanced stage of coronary artery disease.

A correlation between the particular coronary vessel that underwent CE and incidence of MI was not found [12]. However, patients who have had more than single-vessel endarterectomy also had a higher possibility of infarction $[12,13]$.

So far there have been no clear guidelines recommending pharmacotherapy in patients who had CABG + CE. The authors used various models of antiplatelet treatment and anticoagulation. The lack of a single infarction in our cardiac surgery unit allows us to be optimistic about our protocol. We use LMWH until the patient is fully mobilized. Patients receive dual antiplatelet therapy from the first day to the end of the third month after surgery. It proves to be a safe and efficient regimen. However, we intend to expand our observations to a larger group of patients to make this statistically significant.

The association between the CE + CABG procedure and its effect on myocardial function remains controversial. Minale et al. reported a significant fall of EF and contraction disorder in $17.7 \%$ of patients with a trend to arise within the anterior wall. The same study reported EF improvement in $16.5 \%$ of cases [14]. Statistical analysis referring to LAD endarterectomy selectively revealed deterioration of anterior wall contraction in $34 \%$ of patients. It appeared to be most significant in cases without previous dysfunction [15]. Our report does not confirm those observations.

Recently there have been some reports of successful off-pump coronary artery bypass grafting (OPCAB) + CE. This matter needs to be investigated further. However, the efficiency and safety of this approach seem to be quite convincing [16].

It seems that adding coronary artery endarterectomy to the standard coronary artery bypass grafting procedure should be indicated in some cases. This procedure is not an alternative to CABG and it should be regarded as a therapeutic option that is proper in specific patients despite its risk. Ability to make a correct decision and great caution when performing CE are essential in achieving an optimal effect. Benefits from obtaining complete revascularization should overcome potential dangers associated with CE in those patients. Research on a greater number of patients is required, as well as guideline preparation for perioperative care.

\section{Disclosure}

Authors report no conflict of interest.

\section{References}

1. Bell MR, Gersh BJ, Schaff HV, Holmes DR Jr, Fisher LD, Alderman EL, Myers WO, Parsons LS, Reeder GS. Effect of completeness of revascularization on long-term outcome of patients with three-vessel disease undergoing coronary artery bypass surgery. A report from the Coronary Artery Surgery Study (CASS) Registry. Circulation 1992; 86: 446-457.

2. Lawrie GM, Morris GC Jr, Silvers A, Wagner WF, Baron AE, Beltangady SS, Glaeser DH, Chapman DW. The influence of residual disease after coronary bypass on the 5 -year survival rate of 1274 men with coronary artery disease. Circulation 1982; 66: 717-723.

3. Jones EL, Craver JM, Guyton RA, Bone DK, Hatcher CR Jr., Riechwald N. Importance of complete revascularization in performance of the coronary bypass operation. Am J Cardiol 1983; 51: 7-12.

4. Bailey CP, May A, Lemmon WM. Survival after coronary endarterectomy in man. J Am Med Assoc 1957; 164: 641-646.

5. Livesay JJ, Cooley DA, Hallman GL, Reul GJ, Ott DA, Duncan JM, Frazier OH. Early and late results of coronary endarterectomy. Analysis of 3,369 patients. J Thorac Cardiovasc Surg 1986; 92: 649-660.

6. Shapira OM, Akopian G, Hussain A, Adelstein M, Lazar HL, Aldea GS, Shemin RJ. Improved clinical outcomes in patients undergoing coronary artery bypass grafting with coronary endarterectomy. Ann Thorac Surg 1999; 68: 2273-2278.

7. Asimakopoulos G, Taylor KM, Ratnatunga CP. Outcome of coronary endarterectomy: A case-control study. Ann Thorac Surg 1999; 67: 989-993.

8. Djalilian AR, Shumway SJ. Adjunctive coronary endarterectomy: Improved safety in modern cardiac surgery. Ann Thorac Surg 1995; 60: 1749-1754.

9. Sirivella S, Gielchinsky I, Parsonnet V. Results of coronary artery endarterectomy and coronary artery bypass grafting for diffuse coronary artery disease. Ann Thorac Surg 2005; 80: 1738-1744.

10. LaPar DJ, Anvari F, Irvine JN Jr, Kern JA, Swenson BR, Kron IL, Ailawadi G. The impact of coronary artery endarterectomy on outcomes during coronary artery bypass grafting. J Card Surg 2011; 26: 247-253.

11. Byrne JG, Karavas AN, Gudbjartson T, Leacche M, Rawn JD, Couper GS, Rizzo RJ, Cohn LH, Aranki SF. Left anterior descending coronary endarterectomy: early and late results in 196 consecutive patients. Ann Thorac Surg 2004; 78: 867-873.

12. Marzban M, Karimi A, Ahmadi H, Davoodi S, Abbasi K, Movahedi N, Salehiomran A, Abbasi SH, Kawoosi Y, Yazdanifard P. Early outcomes of doublevessel coronary endarterectomy in comparison with single-vessel coronary endarterectomy. Tex Heart Inst J 2008; 35: 119-124.

13. Atik FA, Dallan LA, de Oliveira SA, Lisboa LA, Platania F, Cabral RH, Jatene AD. Myocardial revascularization with coronary endarterectomy. Stratification of risk factors for early mortality. Arq Bras Cardiol 2000; 75: 269-280.

14. Minale C, Nikol S, Zander M, Uebis R, Effert S, Messmer BJ. Controversial aspects of coronary endarterectomy. Ann Thorac Surg 1989; 48: 235-241.

15. Sachweh JS, Messmer BJ, Groetzner J, Vom Dahl J, Fausten B, Daebritz SH. Left anterior descending coronary artery: long-term angiographic results of CABG with endarterectomy. J Cardiovasc Surg (Torino) 2007; 48: 633-640.

16. Takahashi M, Gohil S, Tong B, Lento P, Filsoufi F, Reddy RC. Early and midterm results of off-pump endarterectomy of the left anterior descending artery. Interact Cardiovasc Thorac Surg 2013; 16: 301-306. 